\title{
Sources of economic fluctuations in France: A structural VAR model
}

\author{
Nabil Ben-Arfa, University of Nice Sophia Antipolis, France*
}

\begin{abstract}
This paper studies the economic fluctuations of an open economy such as the French economy. A system of variables containing output, price level, trade balance, real exchange rate and oil prices is analyzed by applying the structural vector autoregressive (SVAR) methodology initiated by Sims (1980). This set of variables allows to evaluate the main sources of impulses of the French economy fluctuations. The results show that five structural shocks are identified using the long-run constraints implemented by Blanchard and Quah (1989). From the SVAR dynamic properties, impulse response functions and variance decomposition, the French economy is shown to be particularly vulnerable to supply and oil price shocks, where these two shocks respectively contribute to $40 \%$ and $35 \%$ of the economic disturbance. France is also hit by important external shocks which damage its trade balance position. Finally, it is found that shocks related to economic policy (demand shocks) have a quite limited impact on the economic activity.
\end{abstract}

\section{JEL Classification}

E32; F41; C22

\section{Keywords}

economic fluctuations; external shocks; internal shocks; oil price shock; SVAR model

DOI: https://doi.org/10.17979/ejge.2012.1.1.4277

\footnotetext{
"Address for correspondence: Nabil Ben Arfa, CEMAFI, University of Nice Sophia-Antipolis, Résidence les Imperators, immeuble le Constantin A, Chemin de la Lauve, 83700 Saint Raphaël, France. E-mail : nabil_ar@yahoo.fr.
} 


\section{Introduction}

The 1980s have operated a methodological and a theoretical revival on the economic fluctuations analysis. The aim of this paper is to deal with empirical treatment of economic disturbances. Sims (1980) was the pioneer of the fluctuations analysis within the vectorial autoregressive model, where impulses are apprehended as innovations in a statistical term. These VAR models were introduced as an alternative to the traditional econometric models. Sims proposed a new form of modeling based on no a priori and where no distinction is made between exogenous and endogenous variables.

Since pioneer work of Sims (1980), the main empirical work dealing with the sources of economic fluctuations lay on autoregressive vectorial model. These canonical VAR models however posed some problems related to the shocks identification, they faced a lot of criticisms, qualifying them as "atheoretical" models. These criticisms lead to the birth of structural VAR models, models in which shocks identification is conducted by the imposition of constraints drawn from economic theory. It is this methodology of structural VAR which will be applied to the French economy. We will apply a structural VAR model to the French economy in order to identify the main shocks which are the origin of the economic activity fluctuations.

In the second section we will reconsider the theoretical and the methodological revival of fluctuations analysis. In the third and the fourth part of the paper we explore the data used and estimate the structural VAR model. Finally, we interpret the results.

\section{The methodological and theoretical revival of the fluctuation analysis:}

The 1980s has operated a methodological and a theoretical revival on the analysis of economic fluctuations. The methodological revival was initiated by Sims (1980); it was inscribed on the line of the impulse-propagation approach suggested by Frisch (1933) and Slutsky (1927).

On a theoretical level, real business cycle theory constitutes a true theoretical revival on the fluctuations analysis: it proposes to explain the main part of the economic fluctuations within the neo-classic growth model disturbed only by shocks affecting the total factor productivity. This marks the abandonment of the debate on the relative importance of monetary versus fiscal shocks. The debate on the relative importance of supply and demand shocks emerges.

\section{Real Business cycle theory}

At the beginning of the eighties, the relevance of the equilibrium monetary theory was rejected in a theoretical as in an empirical level. It is in this context that appears the real business cycles theory, or $\mathrm{RBC}^{1}$, with the pioneers' models of Kydland and Prescott (1982) and Long and Plosser (1983) in closed economy.

The real business cycle theory considers economic fluctuations as the optimal response of economic agents to shocks on the total factor productivity. The models of real business cycle thus conceive the evolution of economic aggregates as the decision result of a great number of agents seeking to maximize their utility and only constrained by technological resource. The real business cycle theory attributes an insignificant role, even no role, to the monetary policy

\footnotetext{
${ }^{1}$ For Real Business Cycles.
} 
These basic models were followed by many extensions: extensions to open economies, with the international real business cycle of Backus, Kehoe and Kydland (1992, 1994, and 1995). Extensions to others shock in addition to the technological shock, by borrowing theoretical assumptions from the Keynesian theory.

Criticisms addressed to the basic real business cycle models lead to the development of an abundant literature, with increasingly sophisticated models. Results of these developments were not always satisfactory especially concerning the reproduction of the stylized facts.

The methodological contribution of the real business cycles theory is however admitted by a large part of economists. Parallel to this movement within the real business cycle theory, a new school of thought was emerging; it is the new Keynesian macroeconomics. The New Keynesian (NK) shares with the partisans of the real business cycle theory the fact that macroeconomic requires more microeconomic bases. However, NK economists believe that market imperfections are the key to understanding the real-world. The introduction of NK ideas into RBC models seems to make results definitely more satisfactory, in the sense that these models are accepted by economics profession and that their empirical results are more realistic.

The introduction of the prices rigidity was sufficient to join again with the monetary policy, neutral and without effect in basic RBC models. Some economists saw in this "marriage" between RBC and Keynesian, the birth of "the New Neo-classical Synthesis" (Goodfriend and King 1997).

Nowadays, macroeconomic models incorporate the principal theoretical elements of RBC models. They adopt their general structure; seek to identify the impulses response function of agent in a general equilibrium structure. On the other hand, the way in which the models define and identify the cycles is substantially different from the original contributions, various types of imperfections and rigidities are introduced. These imperfections proposed by New Keynesian are related to the imperfect nature of competition on goods market, the specificity of financial market exchange, etc.

During last decades, RBC initials disappeared gradually and those of DSGE appear (dynamic stochastic general equilibrium).

\section{The methodological revival: VAR model}

Sims (1980) proposed a tool for fluctuations analysis based on impulses, defined as statistical innovations. Since Sims contribution of 1980, the mains empirical work on the economic fluctuations sources lay on autoregressive vectorial methodology.

The purpose of Sims consists in evaluating the contribution of various innovations of a system to the dynamics of each variable. To distinguish the impulses response from the propagation mechanisms, he proposes the Choleski method of orthogonalization. Following criticisms and in particular those concerning the impossible interpretation of shocks economically through the Choleski decomposition, many authors suggest to base the orthogonalization of shocks on structural model of innovations, the structural VAR model.

Shapiro and Watson (1988), Blanchard and Quah (1989) and Gali (1992), proposed to identify structural impulses, which are interpretable economically: supply shocks, demand, economic policy...Their methods of identification are based on restrictions drawn from the economic theory. From an econometric point of view the structural impulses are estimated as a function of the canonical innovations, obeying to constraints resulting from the economic theory. The imposed restrictions can be of different kind and their economic implications 
diametrically opposite. One distinguishes two types of restrictions used in the recent literature: short term restrictions and long run restrictions.

The short run constraints relate to the instantaneous answers of variable to shocks. Long run restrictions are related to the long term shocks responses. Those developments make the birth of the structural VAR model, i.e VAR models where it is possible to give economic definition to various shocks.

\section{Data characteristics and VAR model estimation}

The purpose of this section is to analyze the economic disturbances in an open economy, the French economy. Empirical study presented in this section is based on the VAR methodology incited by Sims (1980).

These recent developments on time series econometrics are applied to a system of variable including output, prices, trade balance, real exchange rate and oil price. This system of variables makes possible the evaluation of the main source of disturbance in the French economy. So, in an autoregressive vectorial model including these variables, five structural shocks are identified with the help of the Blanchard and Quah (1989) method of decomposition.

\section{Long term characteristics of the data}

Before the model estimation, we must preliminary check the order of integration and test the possible presence of cointegration relationship between variables.

We use quarterly data extending from 1978Q1 to 2007Q4: ${ }^{2}$

- y: GDP logarithm

$\mathrm{p}$ : logarithm of consumer price index

- $s e$ : logarithm of trade balance

- tc: logarithm of the real effective exchange rate

- pp: logarithm of the oil price

\section{Tests of stationarity}

To analyze the long-term properties of the data, we use three different methods: Augmented Dickey-Fuller test (1979), Phillips-Perron test (1988) and KwiatkowskiPhillips-Schmidt-Shin test (1992).

\footnotetext{
${ }^{2}$ Our Data comes from the INSEE (Institut National de la Statistique et des Etudes Economiques) database and the IFS (International Financial Statistics) from the IMF (International Monetary Fund).

- $Q$ for quarter.

- All series are seasonally adjusted. The oil price is in US dollars. The real effective exchange rate is computed with ULCs.
} 
Table 1. Unit root tests

\begin{tabular}{|c|c|c|c|c|c|c|}
\hline \multirow[t]{2}{*}{ Variables } & \multicolumn{2}{|c|}{$\begin{array}{l}\text { Augmented Dickey } \\
\text { Fuller (ADF) }\end{array}$} & \multicolumn{2}{|c|}{$\begin{array}{l}\text { Phillips-Perron } \\
\text { (PP) }\end{array}$} & \multicolumn{2}{|c|}{$\begin{array}{c}\text { Kwiatkowski-Phillips-Schmidt-Shin } \\
\text { (KPSS) }\end{array}$} \\
\hline & $\begin{array}{l}\text { Statistics } \\
\text { of the test }\end{array}$ & $\begin{array}{l}\text { Critical } \\
\text { value } \\
(5 \%)\end{array}$ & $\begin{array}{l}\text { Statistics } \\
\text { of the test }\end{array}$ & $\begin{array}{l}\text { Critical } \\
\text { value } \\
(5 \%)\end{array}$ & $\begin{array}{l}\text { Statistics } \\
\text { of the test }\end{array}$ & Critical value (5\%) \\
\hline GDP & 5.63 & -1.95 & 13.17 & -1.95 & 1.30 & 0.46 \\
\hline$\Delta \mathrm{GDP}$ & -4.92 & $-2.89^{*}$ & -7.55 & $-2.89^{*}$ & 0.05 & 0.46 \\
\hline $\begin{array}{l}\text { Trade } \\
\text { balance }\end{array}$ & -0.17 & 1.95 & -0.03 & 1.95 & 0.60 & 0.46 \\
\hline $\begin{array}{l}\Delta \text { (trade } \\
\text { balance) }\end{array}$ & -5.35 & -1.95 & -10.60 & -1.95 & 0.19 & 0.46 \\
\hline $\begin{array}{l}\text { Real foreign } \\
\text { exchange } \\
\text { rate }\end{array}$ & -1.10 & -1.95 & -1.10 & -1.95 & 1.20 & 0.46 \\
\hline $\begin{array}{c}\Delta \text { (real } \\
\text { foreign } \\
\text { exchange } \\
\text { rate) }\end{array}$ & -9.66 & -1.95 & -9.66 & -1.95 & 0.07 & 0.46 \\
\hline $\mathrm{CPI}$ & -0.05 & -1.95 & -0.05 & -1.95 & 0.54 & 0.46 \\
\hline$\Delta(\mathrm{CPI})$ & -8.72 & -1.95 & -8.72 & -1.95 & 0.05 & 0.46 \\
\hline The oil price & 1.05 & -1.95 & 1.01 & -1.95 & 0.87 & 0.46 \\
\hline $\begin{array}{l}\Delta \text { (Of the oil } \\
\text { price) }\end{array}$ & -8.57 & -1.95 & -8.60 & -1.95 & 0.15 & 0.46 \\
\hline
\end{tabular}

Notes: - * This critical value is relating to the model with constant and without trend.

- The character $\Delta$, indicates the first difference of the variable.

- All the variables are in logarithm.

According to unit root tests, it appears that all the variables of the model are nonstationary; they are integrated of order one.

\section{Cointegration relationship}

To test the possible existence of cointegration between variables, we use the test implemented by Johansen (1991) and Johansen and Juselius (1990). ${ }^{3}$

So we suppose the vector $X_{\text {of dimension }(5 \times 1) \text { : }}$

$X=[y, p, s e, t c, p p]$

The general representation of the model in $\mathrm{VECM}^{4}$ form is given by the following expression:

$\Delta X_{t}=\mathrm{C}+\Pi_{1} \Delta X_{t-1}+\ldots+\Pi_{p-1} \Delta X_{t-p+1}+\Pi X_{t-1}+\varepsilon_{t}$

Where matrices $\Pi_{i}(I=1, \ldots, p)$ are of size $(N \times N)$.

The method suggested by Johansen and Juselius is based on two assumptions: on one hand the vector $X$ must be I (1) and in addition the vector of the residual $\varepsilon$ must be a white noise. The strategy of the test consists in analyzing the rank of

\footnotetext{
${ }^{3}$ The advantage of this method is that it allows for the identification of multiple cointegrating vectors. The Engle-Granger cointegration methodology (Engle and Granger, 1987) is limited to testing only for one cointegrating vector.

${ }^{4}$ VECM for Vector Error Correction Model.
} 
the matrix $\Pi$. If the rank of $\Pi$ is zero then there is no cointegration between the variables. If the rank of the matrix $\Pi$ is $r$, there exist two matrices of dimension (n×r), $\alpha$ and $\beta$ as:

$\Pi=\beta \alpha$

$\alpha$ is a matrix which contains the $r$ vectors of cointegration.

$\beta$ is a matrix which contains the weights associated to each vector of cointegration.

To determine the number of vectors of cointegration $r$, Johansen proposes two statistics: the trace test and the maximum eigenvalue test.

The trace statistic is the following:

$\mathrm{TR}=$ - T $\sum_{i=q+1}^{N} \log \left(1-\hat{\lambda}_{i}\right)$

The Ho hypothesis is: $r \leq q$, i.e. there are at least $r$ vectors of cointegration. This test is equivalent to test the rank of the matrix $\Pi$ since testing the existence of $r$ vectors is equivalent to test the following null assumption:

$\operatorname{Rg}(\Pi)=r$

Three cases can be presented:

$\operatorname{Rg}(\Pi)=0$, this means that $r=0$ : there is no cointegration, in other words $X_{t}$ is integrated of order 1 but not cointegrated. It is then possible to estimate a VAR model on $\Delta X_{t}$.

$\operatorname{Rg}(\Pi)=r$, with $r<\mathrm{N}$ : $X_{t}$ is cointegrated with $r$ rank, thus $r$ relations of cointegration exist. A VECM can be estimated.

$\operatorname{Rg}(\Pi)=\mathrm{N}$, in this case the matrix $\Pi$ is full rank, $X_{t}$ is stationary, and there is no cointegration. A VAR model can be estimated directly on ${ }^{X_{t}}$.

The maximum eigenvalue test statistic is:

$V P_{\max }=-T \log \left(1-\hat{\lambda}_{q+1}\right)$

The Ho hypothesis is $r=q$, the alternative one is $r=q+1$.

The results of these tests are conditional to the VAR estimation, and consequently to the lag choice. We have used AIC criterion, the selected lag number is equal to 3 . We carry out tests by supposing the absence of trend and constant in the relationship of cointegration and in the VECM model. 
Table 2. Cointegration test: trace test

\begin{tabular}{ccccc}
\hline Assumption & Eigenvalue & Trace Statistic & Critical value: 5\% & Probability \\
\hline $\mathrm{r}=0$ & 0.193010 & 48.02 & 69.81 & 0.7207 \\
$\mathrm{r} \leq 1$ & 0.082414 & 23.15 & 47.85 & 0.9585 \\
$\mathrm{r} \leq 2$ & 0.075934 & 13.17 & 29.79 & 0.8835 \\
$\mathrm{r} \leq 3$ & 0.024574 & 4.01 & 15.49 & 0.9024 \\
$\mathrm{r} \leq 4$ & 0.009677 & 1.12 & 3.84 & 0.2882 \\
\hline
\end{tabular}

According to the results appearing in the table 2, we accept the null hypothesis of absence of cointegration (48.02< 69.81). Max-eigenvalue test (table 3) also indicates no cointegration at the 0.05 level.

Table 3. Cointegration test: Maximum Eigenvalue test

\begin{tabular}{ccccc}
\hline Assumption & Eigenvalue & $\begin{array}{c}\text { Max-Eigen } \\
\text { Statistic }\end{array}$ & Critical value: $5 \%$ & Probability \\
\hline$r=0$ & 0.193010 & 24.87 & 33.87 & 0.3935 \\
$r \leq 1$ & 0.082414 & 9.97 & 27.58 & 0.9852 \\
$r \leq 2$ & 0.075934 & 9.16 & 21.13 & 0.8193 \\
$r \leq 3$ & 0.024574 & 2.88 & 14.26 & 0.9540 \\
$r \leq 4$ & 0.009677 & 1.12 & 3.841 & 0.2882 \\
\hline
\end{tabular}

Finally, the various tests carried out, we conclude by the rejection of the stationarity and cointegration of the five series in level, so we specify a model in first difference. The VAR model will be consequently built on the growth rate of GDP $(\Delta y)$, on the first difference of real effective exchange rate $(\Delta t c)$, on the first difference of trade balance rate $(\Delta s e)$, on the inflation rate $(\Delta p)$ and on the first difference of oil price $(\Delta \mathrm{pp})$.

\section{VAR model identification}

Basing on results found below, the VAR model in matrix form is the following:

$$
X_{t} \sum_{i=1}^{p} A_{i} X_{t-i}+\varepsilon_{t}
$$

$X_{t}=(\Delta \mathrm{pp}, \Delta s e, \Delta y, \Delta t c, \Delta p,)^{\prime}$, the column vector of the explained variables which depends on its $p$ lags.

$A_{i}$, are the square matrices of the coefficients to be estimated.

$\varepsilon_{t}$, is the vector of the residuals.

$\varepsilon_{t}=\left(\varepsilon_{\Delta p p}, \varepsilon_{\Delta s e}, \varepsilon_{\Delta y}, \varepsilon_{\Delta t c}, \varepsilon_{\Delta p},\right)$ 'represents at each moment $\mathrm{T}$, the value of $X_{t}$ which is not explained by its past. These residuals are also regarded as innovations or impulses.

From the vector of variables ${ }^{X_{t}}$, we will define five shocks: a supply shock, a real demand shock, a nominal demand shock, an external shock (shock on the trade balance) and an oil price shock.

We consider the residual resulting from the first equation as an oil price shock, the one resulting from the second equation as an external shock, that resulting from 
the GDP equation as a supply shock and finally residuals resulting from the fourth and the fifth equation are supposed to be demand shocks (real and nominal).

However, this definition of the shocks is likely to be false since the residuals resulting from a canonical VAR model are often correlated. Consequently, we will adopt the structural VAR method in which shocks identification is based on constraints resulting from the economic theory.

\section{Identifying constraints}

We adopt the structural VAR methodology developed by Blanchard and Watson (1986), Bernanke (1986), Shapiro and Watson (1988), Blanchard and Quah (1989).

Two types of restrictions are mentioned in the literature; short-run restrictions and long-run restrictions. To identify the structural shocks, we choose the identification of Blanchard and Quah (1989) imposing long run constraints. ${ }^{5}$ In other words we will constrain certain variables not to have long-term effects.

We attempt to estimate the following structural VAR model:

$$
\left[\begin{array}{l}
\Delta p p \\
\Delta s e \\
\Delta y \\
\Delta t c \\
\Delta p
\end{array}\right]_{=} D(L) \times\left[\begin{array}{l}
\mu_{\Delta p p} \\
\mu_{\Delta s e} \\
\mu_{\Delta y} \\
\mu_{t c} \\
\mu_{\Delta p}
\end{array}\right]
$$

The left part of this equality describes the vector of variables entering into the VAR system. The right-hand side, is a mixture of the structural shocks, ${ }^{\mu}$ (exogenous forces of the system), and of the matrix $D(L)$ which describes the coefficients associated to these shocks.

The identification of the structural shocks is done by imposing long run constraints using the matrix $\mathrm{D}(1)$.

The long-term answers to shocks are defined by this matrix:

$$
D(1)=\left(\begin{array}{lllll}
d_{11}(1) & d_{12}(1) & d_{13}(1) & d_{14}(1) & d_{15}(1) \\
d_{21}(1) & d_{22}(1) & d_{23}(1) & d_{24}(1) & d_{25}(1) \\
d_{31}(1) & d_{32}(1) & d_{33}(1) & d_{34}(1) & d_{35}(1) \\
d_{41}(1) & d_{42}(1) & d_{43}(1) & d_{44}(1) & d_{45}(1) \\
d_{51}(1) & d_{52}(1) & d_{53}(1) & d_{54}(1) & d_{55}(1)
\end{array}\right)
$$

The identification of shocks in a system of 5 variables requires 10 constraints:

First constraints are drawn from the open economy assumption. It results from this hypothesis that domestic shocks do not affect the variables generating the external shocks: $d_{13}(1)=d_{14}(1)=d_{15}(1)=d_{23}(1)=d_{24}(1)=d_{25}(1)=0$. We can then identify 6 constraints.

\footnotetext{
${ }^{5}$ Our choice is justified; this kind of restriction is applied only in the case of integrated variable which is the case of our model.
} 
Following constraints are drawn from the theoretical assumption commonly accepted since the work of Blanchard and Quah (1989). It is about the distinction between supply and demand shocks. Indeed, economic theory supposes that supply shocks can affect economic activity on the long term. Whereas demand shocks affect economic activity only on the short term. It results two additional constraints: $d_{34}(1)=d_{35}(1)=0$

Concerning the constraints that allow the distinction between the two demand shocks, real demand shock (generally assimilated to a fiscal shock or a foreign exchange rate shock) and the nominal demand shock (monetary shock for example). A real demand shock is supposed to have an effect on real foreign exchange rate whereas a nominal shock does not affect the foreign exchange rate.

It results an additional constraint: $d_{45}(1)=0$.

Finally the last constraint is related to the oil price: an oil price shock is supposed to be the only shock which can have long-term effects on the oil price. This assumption gives us a last constraint: ${ }^{6}$

$$
d_{12}(1)=0
$$

Thus the matrix representing the effects of structural shocks on the model variables is the following one:

$$
D(1)=\left(\begin{array}{ccccc}
d_{11}(1) & 0 & 0 & 0 & 0 \\
d_{21}(1) & d_{22}(1) & 0 & 0 & 0 \\
d_{31}(1) & d_{32}(1) & d_{33}(1) & 0 & 0 \\
d_{41}(1) & d_{42}(1) & d_{43}(1) & d_{44}(1) & 0 \\
d_{51}(1) & d_{52}(1) & d_{53}(1) & d_{54}(1) & d_{55}(1)
\end{array}\right)
$$

After the constraints identification, the estimation of the VAR model requires the determination of the lag. We use the criterion test of information.

\section{Lag selection criteria}

The results of $\mathrm{AIC}, \mathrm{SC}$ and $\mathrm{HQ}$ are exposed in the following table.

Table 3. Lag selection criteria of the VAR model

\begin{tabular}{ccccccc}
\hline Lag & LogL & $L R$ & FPE & AIC & SC & $H Q$ \\
\hline 0 & 1497.285 & NA & $1.45 \mathrm{e}-18$ & -26.88801 & $-26.76596^{*}$ & $-26.83850^{*}$ \\
1 & 1531.364 & 64.47411 & $1.23 \mathrm{e}-18$ & -27.05160 & -26.31930 & -26.75453 \\
2 & 1559.340 & $50.40804^{*}$ & $1.17 \mathrm{e}-18^{*}$ & $-27.10523^{*}$ & -25.76267 & -26.56059 \\
3 & 1570.737 & 19.50838 & $1.50 \mathrm{e}-18$ & -26.86013 & -24.90732 & -26.06793 \\
4 & 1589.531 & 30.47622 & $1.70 \mathrm{e}-18$ & -26.74831 & -24.18524 & -25.70855 \\
\hline
\end{tabular}

* indicates lag order selected by the criterion

This assumption allows the identification of these four
constraints: $d_{12}(1)=d_{13}(1)=d_{14}(1)=d_{15}(1)=0$. We take the first one, $d_{12}(1)=0$, since
the three remaining ones were already taken into account using the assumption of independence
between internal shocks and external shocks.


The results of AIC tests, SC and $\mathrm{HQ}$, give different conclusions: the order of the VAR model is equal to 1 according to criteria $S C$ and $H Q$, it is equal to 3 according to the criterion of AIC, FPE and LR

The majority of lag length criteria suggest the use of a lag of 3 in the analysis. We then take $p=3$.

\section{Estimation of the structural VAR model: impulse response functions and variance decomposition}

\section{Impulse response functions and variance decomposition}

SVAR model estimation is conducted by estimating the ordinary VAR model7, then we apply the long term identifying constraints previously identified, and finally we determinate the structural shocks, their impacts and their contributions to the French economy fluctuations.

\section{Sources of growth rate fluctuations}

Chart 1 represents the response impulse functions of growth rate to the various shocks. It shows the effects of the five shocks on the growth rate. We notice a positive and significantly persistent effect of supply shocks in short-term us in the long run. However, the real and nominal demand shocks affect the economic activity only transitorily.

\footnotetext{
${ }^{7}$ Main validation tests of the VAR model are reported in the appendix.
} 
Chart 1. Impulse response functions of the growth rate
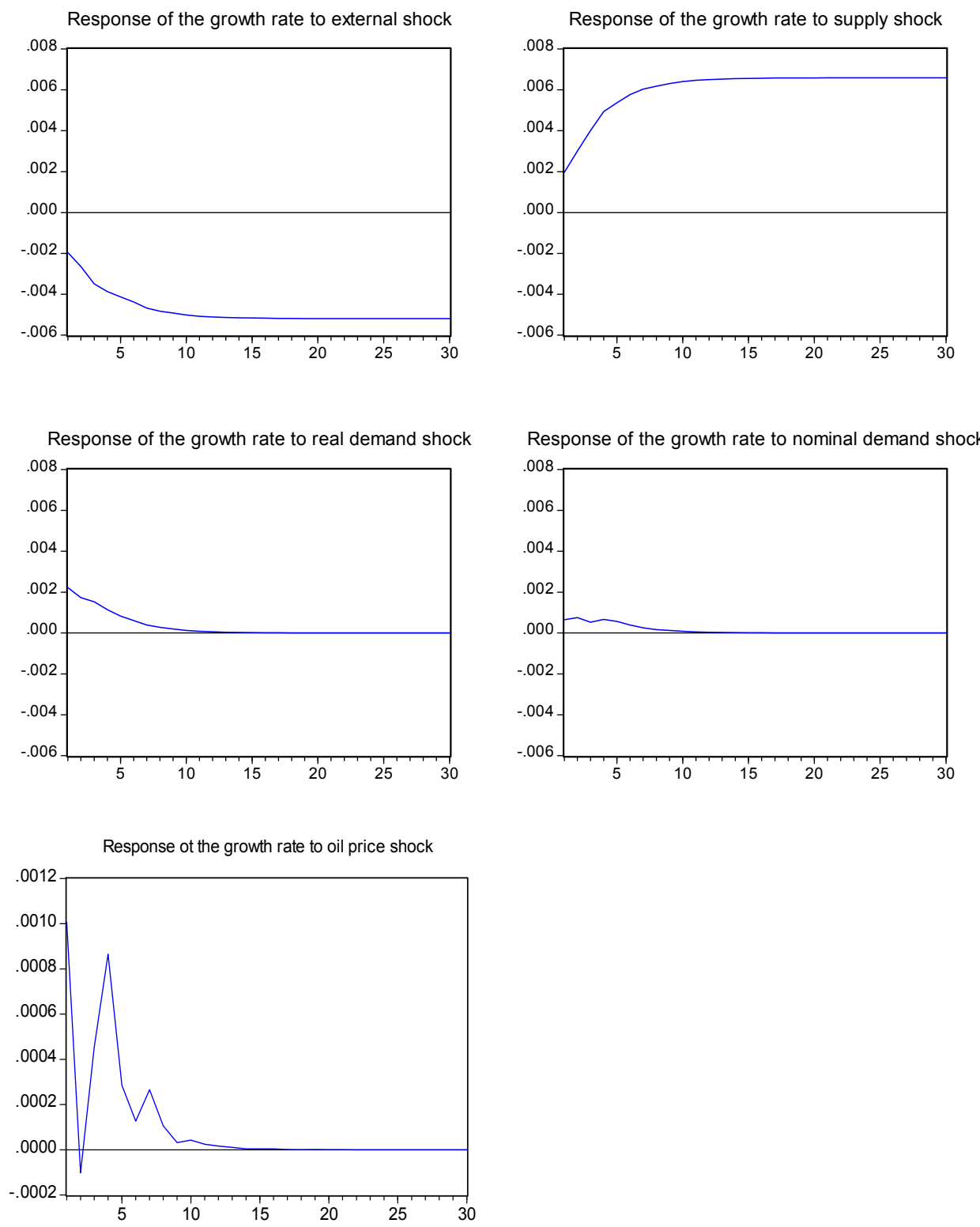

Indeed, as it was predicted by economic theory, a positive supply shock involves an improvement of the activity level, this improvement remains rather bearable in long-term. However, demand shocks have insignificant impact, their impacts tend to be equal to zero in long term.

Concerning the external shocks, the impulse response functions show a negative effect of these shocks on the trade balance. This negative effect can be explained by the degradation of price competitiveness of France resulting from the progressive appreciation of the euro compared to the dollar, which leads to a fall in exports and to an economic activity decrease. This degradation can also be explained by the rise of the oil price or other reasons.

Moreover and basing on the model results we notice the importance of the oil price effect on economic activity. The GDP impulse response function to shocks shows an important effect of oil price shock on the activity level. The growth rate responds negatively to oil price shock. The initial response is the largest one; in long run the 
effect tends to be insignificant. Jalles (2009) adopts several oil price specifications and also found a significant impact of oil price shock on French economic activity.

Table 4. Variance decomposition of the growth rate

\begin{tabular}{cccccc}
\hline Quarters & $\begin{array}{c}\text { Oil price } \\
\text { shock }\end{array}$ & $\begin{array}{c}\text { External } \\
\text { shock }\end{array}$ & Supply shock & $\begin{array}{c}\text { Real demand } \\
\text { shock }\end{array}$ & $\begin{array}{c}\text { Nominal } \\
\text { demand shock }\end{array}$ \\
\hline 1 & 42.28251 & 22.08729 & 21.31262 & 2.140815 & 12.17676 \\
4 & 39.02417 & 15.70284 & 34.68763 & 2.843572 & 7.741792 \\
8 & 35.08653 & 14.36379 & 41.12939 & 2.342595 & 7.077686 \\
12 & 34.60134 & 13.57045 & 43.22037 & 2.148490 & 6.459353 \\
16 & 34.42554 & 13.13336 & 44.23477 & 2.048563 & 6.157772 \\
20 & 34.33957 & 12.85764 & 44.77958 & 1.996534 & 6.026670 \\
24 & 34.29383 & 12.67877 & 45.06698 & 1.968955 & 5.991462 \\
28 & 34.25937 & 12.56120 & 45.22237 & 1.954872 & 6.002194 \\
30 & 34.24477 & 12.51787 & 45.27105 & 1.950650 & 6.015659 \\
\hline
\end{tabular}

The table above reveals the contribution of each shock to the growth rate fluctuations. We notice the prevalence of supply and oil price shocks in the explanation of the growth rate dynamics. Indeed, whatever the chosen horizon, short or long run, oil price shock explains between $40 \%$ and $35 \%$ of the activity variability, the supply shock explains between $21 \%$ and $45 \%$ of the variability. France, as an importer of oil energy, is particularly vulnerable to oil price shock.

Concerning demand shocks, it arises from the variance decomposition, that these shocks have a limited contribution on the long-term economic activity. This consolidates our theoretical assumptions, stipulating that demand shocks do not have a permanent effect on the GDP. Demand shocks (real or nominal) contribute to less than $6 \%$ in the economic activity variability.

In addition, the introduction of the assumption of an open economy into our model enables us to evaluate the contribution of external shocks apprehended in this case by shocks on the trade balance. This shock has a considerable effect on the economic activity; its contribution turns around $12 \%$ in the long term and exceeds $22 \%$ in the short term.

To summarize, the variance decomposition of GDP shows a prevalence of supply and oil price shocks in the economic fluctuation explanation.

\section{Sources of price fluctuations}

Chart 2 indicates a positive impact of nominal demand shocks. These nominal demand shocks reflect the evolution of the money supply and highlight the narrow correlation between the price level and the monetary aggregates. Chart 2 highlights the fact that a nominal demand shock leads to an increase in the general prices level. The raising of prices remains constant on the long term.

In addition, the impulse response functions reveal the importance of supply shocks contribution in the variation of the price level. A positive supply shock (technological shock for example) will make the production more efficient, leads to an increase in output and thus lower the price level as it shown in the chart below. The effects of supply shocks are also more important than those of the real demand shocks.

This result can be explained by the limited effects of the French fiscal policy since the European Pact of Stability constraints the budget deficit to only $3 \%$ of the GDP. 
Chart 2. Impulse response functions of the inflation rate

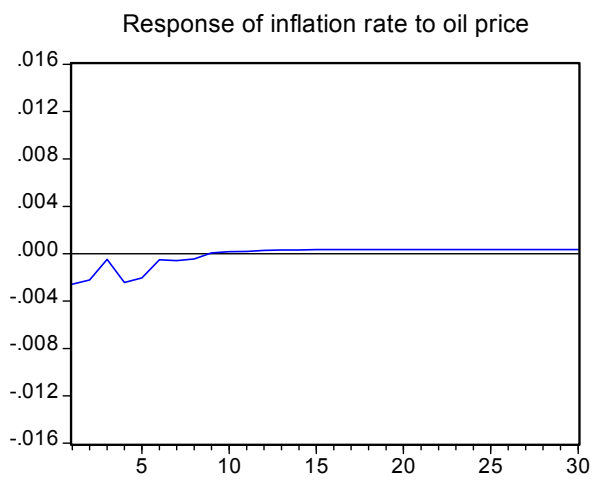

Response of inflation rate to external shock
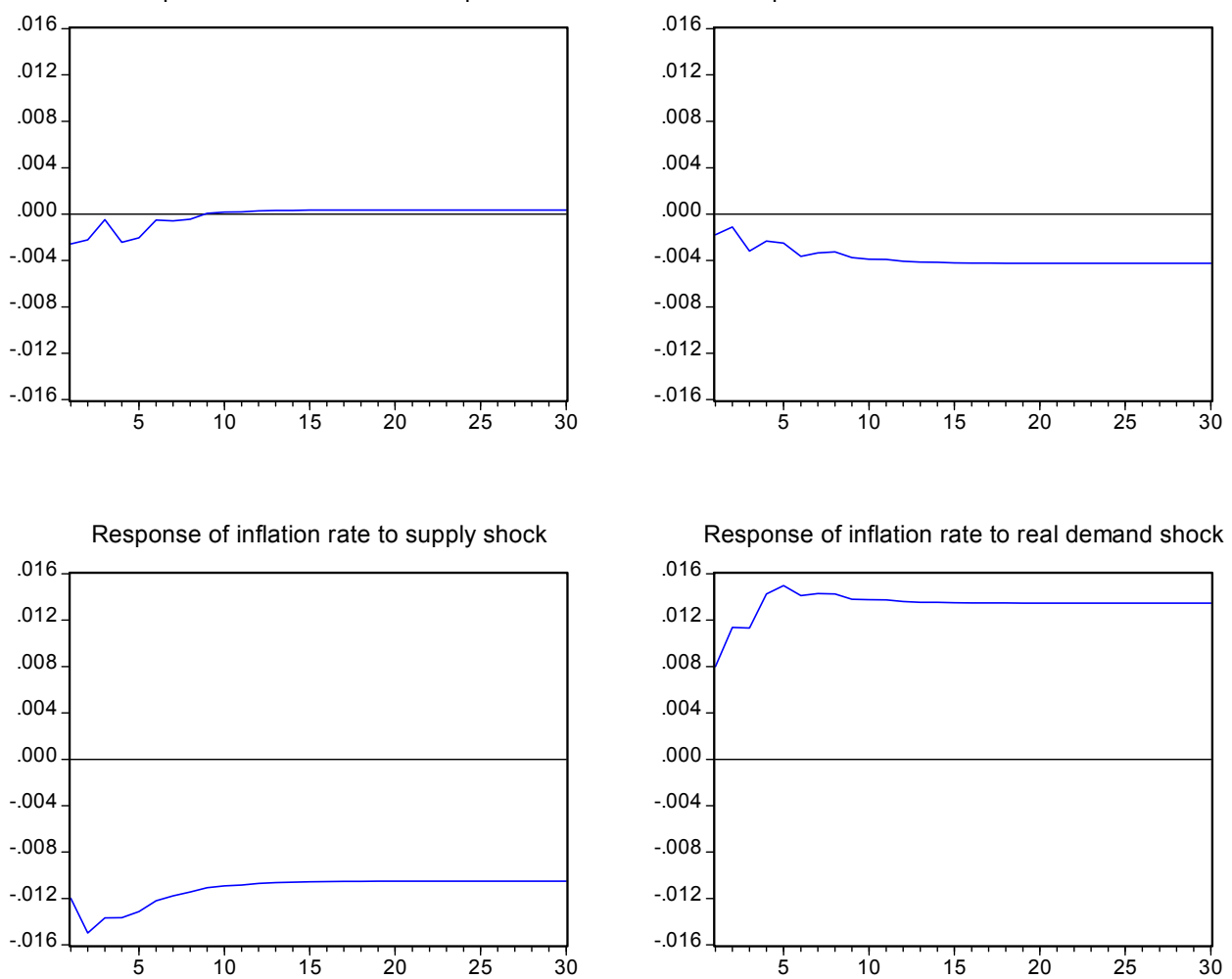

Response of inflation rate to nominal demand shock
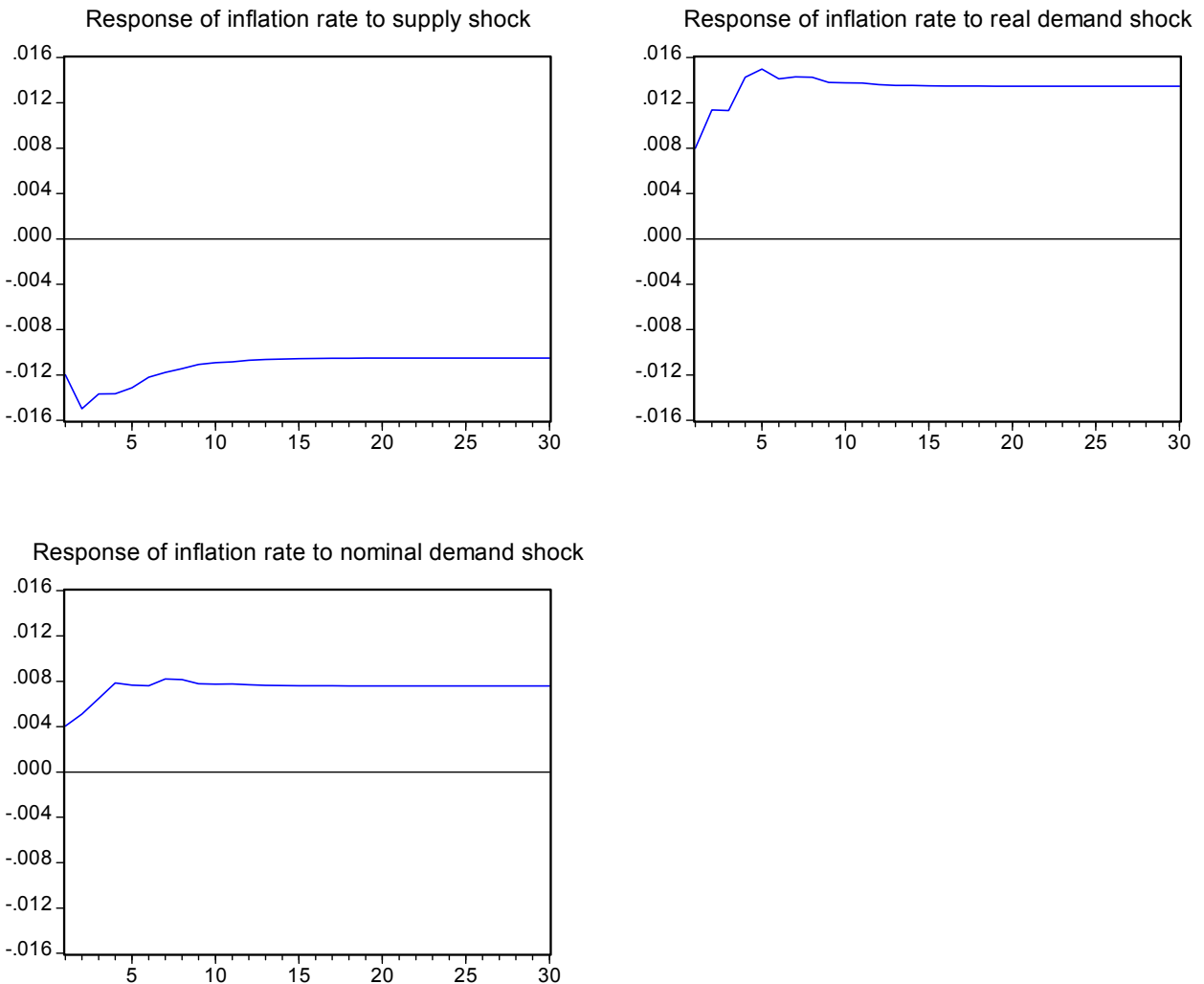
Table 5. Variance decomposition of the inflation rate

\begin{tabular}{cccccc}
\hline Quarters & $\begin{array}{c}\text { Oil price } \\
\text { shock }\end{array}$ & $\begin{array}{c}\text { External } \\
\text { shock }\end{array}$ & Supply shock & $\begin{array}{c}\text { Real demand } \\
\text { shock }\end{array}$ & $\begin{array}{c}\text { Nominal } \\
\text { demand shock }\end{array}$ \\
\hline 1 & 0.013192 & 1.025571 & 58.29633 & 14.97440 & 25.69051 \\
4 & 4.960914 & 3.455207 & 48.21400 & 11.05525 & 32.31463 \\
8 & 7.848685 & 5.708743 & 38.26513 & 8.535835 & 39.64161 \\
12 & 10.09025 & 5.150766 & 36.00894 & 7.568884 & 41.18117 \\
16 & 11.47424 & 4.805916 & 35.80208 & 7.048559 & 40.86920 \\
20 & 12.38600 & 4.537079 & 36.00211 & 6.705005 & 40.36980 \\
24 & 13.03210 & 4.340852 & 36.28109 & 6.471194 & 39.87476 \\
28 & 13.48659 & 4.200097 & 36.54344 & 6.309716 & 39.46016 \\
30 & 13.66247 & 4.145376 & 36.65760 & 6.247748 & 39.28680 \\
\hline
\end{tabular}

The variance decomposition of inflation rate shows a very substantial contribution of impulses conducted by the economic policy. The contribution is more important for nominal demand shocks, about $40 \%$. This prevalence of nominal demand shocks remains stable whatever the time horizon. In addition, as we have notice when dealing with impulse functions, supply shocks contribute to a significant part on inflation rate variation, a contribution which turns around $35 \%$.

Finally, considering the importance of the French economy openness degree, it would be interesting to highlight the external shocks impact on the price level. Through the variance decomposition, we notice a very weak contribution of the trade balance shock on prices disturbances. This contribution is approximately about $4 \%$ in the long term, less than $1 \%$ in the short term.

We also notice that an oil price shock is accompanied by an increase in the price level essentially in long term. In the short term the relative contribution of the oil price shock is almost equal to zero, however in the long term it turns around $13 \%$. This increase (even if it remains controlled enough) cuts down the purchasing power of households, decreases consumption and consequently the growth rate. The oil prices rise of these last years, combined with an unstable geopolitical environment, seems to be durable not temporally. One can expect a continuous rise of oil prices; the economic policies should take into account this new international evidence by defining more rigorous energetic policies. 


\section{Sources of foreign exchange rate fluctuations}

Chart 3. Impulse response functions of the foreign exchange rate
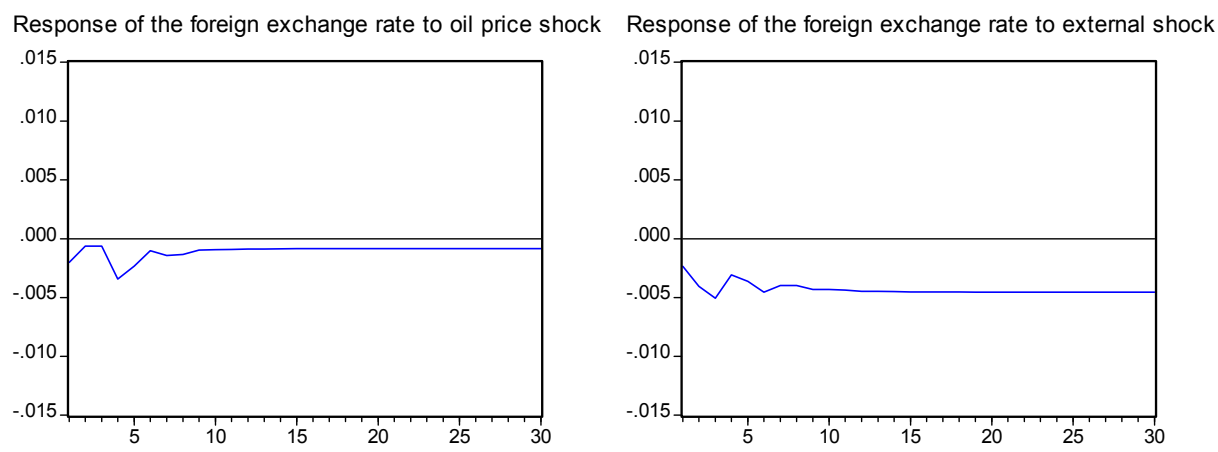

Response of the foreign exchange rate to supply shock Response of the foreign exchange rate to real demand shock
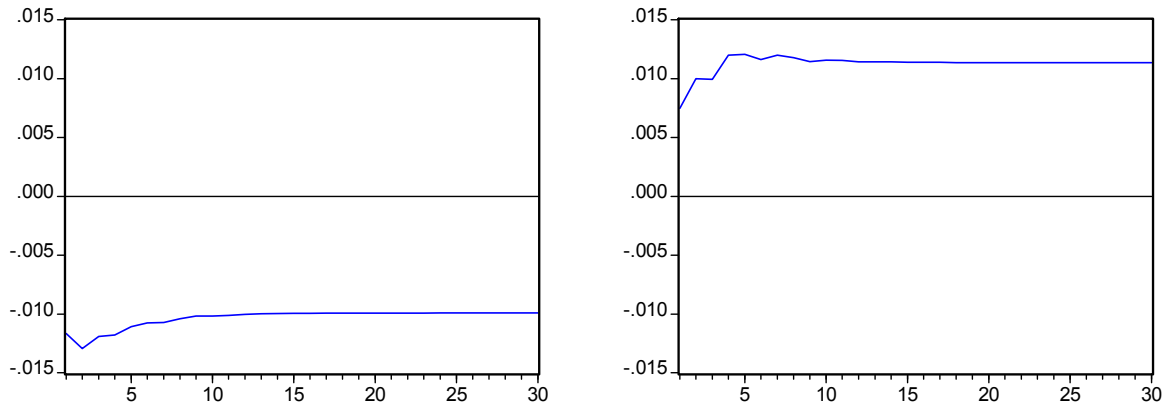

Response of the foreign exchange rate to nominal demand shock

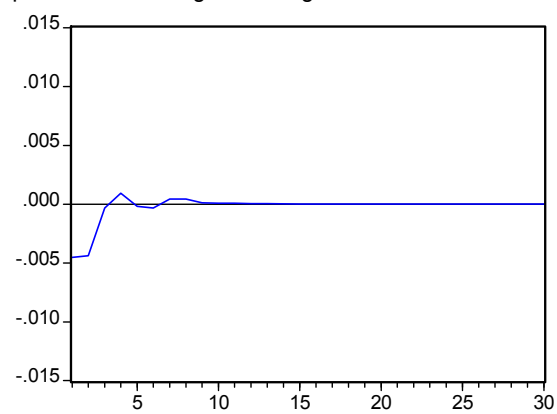


Table 6. The variance decomposition of the foreign exchange rate

\begin{tabular}{cccccc}
\hline Quarters & $\begin{array}{c}\text { Oil price } \\
\text { shock }\end{array}$ & $\begin{array}{c}\text { External } \\
\text { shock }\end{array}$ & Supply shock & $\begin{array}{c}\text { Real demand } \\
\text { shock }\end{array}$ & $\begin{array}{c}\text { Nominal } \\
\text { demand shock }\end{array}$ \\
\hline 1 & 4.913600 & 8.474808 & 36.02216 & 50.33014 & 0.259295 \\
4 & 6.114626 & 10.06832 & 34.76513 & 47.35129 & 1.700633 \\
8 & 6.894016 & 11.43277 & 33.69233 & 45.72826 & 2.252634 \\
12 & 7.018748 & 11.34274 & 33.99508 & 45.26362 & 2.379807 \\
16 & 7.080580 & 11.33318 & 34.02144 & 45.18350 & 2.381303 \\
20 & 7.098915 & 11.32942 & 34.04914 & 45.14051 & 2.382014 \\
24 & 7.111069 & 11.32563 & 34.06474 & 45.11766 & 2.380897 \\
28 & 7.117800 & 11.32325 & 34.07302 & 45.10537 & 2.380558 \\
30 & 7.120032 & 11.32233 & 34.07584 & 45.10117 & 2.380622 \\
\hline
\end{tabular}

From the table above, we notice a prevalence of domestic shocks in the explanation of exchange foreign rate fluctuations; particularly the real demand shock, which is assimilated in our model to a fiscal shock or to an adjustment of foreign exchange rate. Indeed, they contribute to approximately $50 \%$ of the foreign exchange rate disturbance.

Concerning the nature of the impact, theoretically a real demand shock due to the aggravation of budget deficit involves an appreciation of the real foreign exchange rate and a deterioration of the external position.

Our empirical results are in conformity with this theoretical assumption. Impulses response functions show an appreciation of the real foreign exchange rate when the economy is hit by a real demand shock which is probably caused by the overvaluation of the euro/dollar exchange rate since the fiscal policy in France is relatively controlled (the European pact of stability).

Concerning the remainder of domestic shocks, we notice a quite high contribution of supply shocks and a very limited contribution of nominal demand shocks; they respectively contribute to $36 \%$ and $2 \%$ of disturbances. Impulses response functions reveal that the effects of nominal demand shocks are unstable and close to zero. In other hand a positive supply shocks involves a depreciation of the real foreign exchange rate.

Finally concerning the contribution of external and oil price shocks to foreign exchange rate fluctuations; it appears from the variance decomposition that these two shocks have a significant contribution but still lower in comparison to internal shocks. Indeed, the external shocks contribute to approximately $11 \%$ of the foreign exchange rate variability, oil price shocks contribute to $7 \%$.

Taking into account these results, we can conclude that foreign exchange rate disturbance is due primarily to real demand shocks; they contribute to approximately $50 \%$. 


\section{Sources of trade balance fluctuations}

Chart 4. Impulse response functions of the trade balance
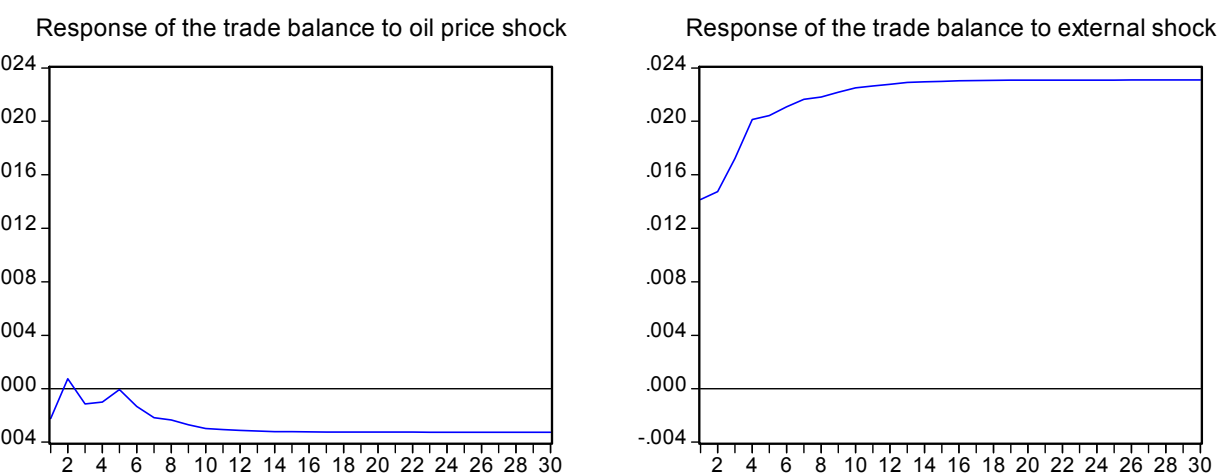

Response of the trade balance to supply shock

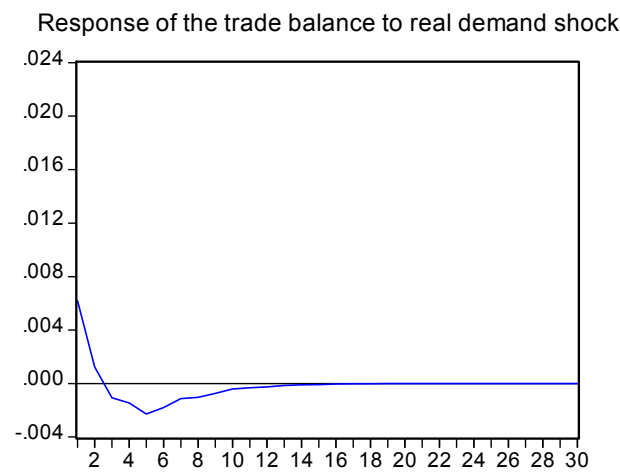

Response of the trade balance to nominal demand shock

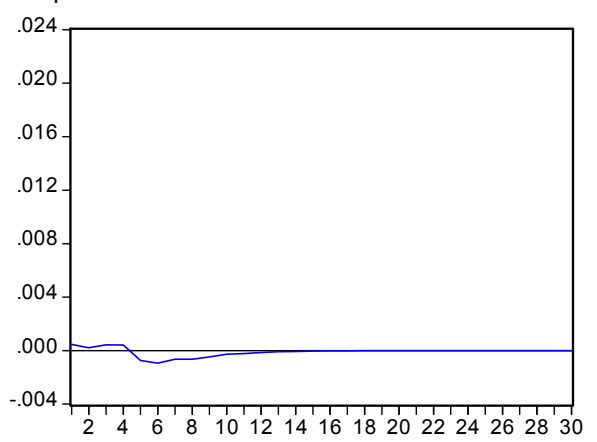


Table 7. Variance decomposition of the trade balance

\begin{tabular}{cccccc}
\hline Quarters & $\begin{array}{c}\text { Oil price } \\
\text { shock }\end{array}$ & $\begin{array}{c}\text { External } \\
\text { shock }\end{array}$ & Supply shock & $\begin{array}{c}\text { Real demand } \\
\text { shock }\end{array}$ & $\begin{array}{c}\text { Nominal } \\
\text { demand shock }\end{array}$ \\
\hline 1 & 0.482441 & 50.32980 & 6.364164 & 7.407492 & 35.41610 \\
4 & 4.023561 & 46.26756 & 7.478640 & 10.91904 & 31.31119 \\
8 & 6.074570 & 42.74174 & 8.056011 & 11.02374 & 32.10393 \\
12 & 6.318011 & 42.39966 & 8.081979 & 11.24891 & 31.95144 \\
16 & 6.328384 & 42.36155 & 8.091934 & 11.25460 & 31.96354 \\
20 & 6.329172 & 42.35446 & 8.094050 & 11.25585 & 31.96647 \\
24 & 6.329163 & 42.35283 & 8.093642 & 11.25604 & 31.96833 \\
28 & 6.329101 & 42.35188 & 8.093429 & 11.25587 & 31.96971 \\
30 & 6.329075 & 42.35161 & 8.093417 & 11.25587 & 31.97003 \\
\hline
\end{tabular}

Based on the response impulse functions and the Variance decomposition table, one notices the importance of nominal demand shocks; they contribute to approximately $30 \%$ of the trade balance variation in short as in long term. The remainder shocks have an insignificant effect on the trade balance. However, it is important to underline that an increase in oil prices contributes to the appreciation of real exchange rate in the short term and to its depreciation in the long term.

Since the EMU, appreciation of the euro/dollar exchange rate worsens the French external position. The improvement of the French external balance position should be made by the amelioration of terms of trade, by the diversification of its business partners especially by the acquisition of new market shares (emergent market), by reducing labour cost, or by investing in research and innovation, etc.

\section{Conclusion}

The results founded in this paper underline the French vulnerability to internal as to external shocks. They especially highlight the importance of supply and oil price shocks in economic fluctuations. Indeed, through the two VAR models instruments (impulse response function and variance decomposition), we clearly notice the prevalence of supply shocks in the explanation of GDP fluctuations (between $21 \%$ and $45 \%$ depending in time horizon).

Oil prices shocks explain between $40 \%$ and $35 \%$ of economic disturbance. France, as a net importer of oil energy, is particularly vulnerable to oil price shocks; oil shock has a negative and durable effect on the economic activity. So it is important to find alternative solutions to reduce the economy dependence on oil energy.

Concerning demand shocks, particularly those relating to monetary and fiscal policies. Results show that their effects are quite limited; this is probably due to the restrictive European economic policies adopted since the 1990s, and which is strongly controlled since the 1st January 1999 with the establishment of the European Monetary Union.

The improvement of the French economic activity requires a better coordination, a better governance of the European economic policies. It also requires the improvement of the energy policies in order to attenuate the French economy dependence.

Regarding the French external position, a position to be taken seriously into account, France must encourage firms to invest and innovate to improve the competitiveness. France should benefit from the strong growth of emergent countries like China or India by orientating its exports towards sectors in expansion. It should also follows the German example by encouraging investments in small and medium-size companies. 


\section{References}

Backus, David and Patrick Kehoe (1992) 'International Evidence of the Historical Properties of Business Cycles', American Economic Review, 82(4): 864-888.

Backus, David, Patrick Kehoe and Finn E. Kydland (1992) 'International Real Business Cycles', Journal of Political Economy, 100(4): 745-775,

Backus, David, Patrick Kehoe and Finn E. Kydland (1994) 'Dynamics of the Trade Balance and the Terms of Trade: The J-Curve? ', American Economic Review, 84(1): 84-103.

Backus, David, Patrick Kehoe and Finn E. Kydland (1995) 'International Business Cycles: Theory and Evidence', in Thomas F. Cooley (ed) Frontiers of Business Cycle Research, pp. 331-356. Princeton, NJ: Princeton University Press.

Bernanke, Ben S. (1986) 'Alternative explanations of the money-income correlation', Carnegie-Rochester Conference Series on Public Policy, 25: 49-99.

Blanchard, Oliver J. and Mark W. Watson (1986) 'Are Business Cycle all Alike', in Robert Gordon (ed.), The American Business Cycle: Continuity and Change, pp. 123-156. Chicago: University of Chicago Press.

Blanchard, Oliver J. and Danny Quah (1989) 'The Dynamic Effects of Aggregate Demand and Supply Disturbances', American Economic Review, 79(4): 655-673.

Blinder, Alan and Stephen M. Goldfeld S (1976) 'New Measures of Fiscal and Monetary Policy, 1958-73', American Economic Review, 66(5): 780-796.

Dickey, David and Wayne Fuller (1979) 'Distribution of the Estimators for Autoregressive Time Series with a Unit Root,' Journal of the American Statistical Association, 74(366): 427-431.

Engle, Robert F. and Clive W. J. Granger C. (1987) 'Cointegration and Error Correction Representation, Estimation and Testing', Econometrica, 55(2) :251-276.

Frisch, Ragnar (1933) 'Propagation and Impulses Problems in Dynamic Economics', in Economics Essays in honour of Gustav Cassel, pp. 171-205. London: Allenunwin Georges.

Gali, Jordi (1992) 'How Well Does the IS-LM Model fit Post war U.S Data?', Quarterly Journal of Economics, 107(2): 709-738.

Goodfreind, Marvin and Robert G. King (1997) 'The New Classical Synthesis and the Role of Monetary Policy', NBER Macroeconomics Annual, Cambridge, MIT Press.

Jalles, Joao T. (2009) 'Do Oil Prices Matter? The Case of a Small Open Economy', Annals of Economics and Finance 10(1): 65-87

Johansen, Soren (1991) 'Estimation and Hypothesis Testing of Cointegration Vector in Gaussian Vector Autoregressive Models', Econometrica, 59(6): 15511580.

Johansen, Soren and Katarina Juselius. (1990) 'Maximum Likelihood Estimation and Inference on Cointegration-with Applications for the Demand for Money', Oxford Bulletin of Economics and Statistics, 52(2): 169-210.

Keating, John W. (1992) 'Structural Approaches to Vector Autoregressions', Federal Reserve Bank of St Louis Journal Review, 74(4): 37-57.

Kwiatkowski, Denis, Peter C.B. Phillips, Peter Schmidt and Yongcheol Shin(1992) 'Testing the Null Hypothesis of Stationarity Against the Alternative of a Unit Root,' Journal of Econometrics, 54(1-3): 159-178.

Kydland, Finn E. and Edward C. Prescott (1982) 'Time to Build and Aggregate Fluctuations', Econometrica, 50(6): 1345-1370. 
Kydland, Finn E. and Edward C. Prescott (1991)' The Econometrics of the General Equilibrium Approach to Business Cycles', Scandinavian Journal of Economics, 93(2): 161-178.

Long, John B. and Charles Plosser (1983) 'Real Business Cycle', Journal of Political Economy, 91(1): 39-69.

McCallum, Bennett T. (1989) 'Real Business Cycles Models', in Robert J. Barro (ed) Modern Business Cycles Theory, pp. 16-50. Oxford : Basil Blackwell.

Phillips, Peter C.B. and Pierre Perron (1988). 'Testing for Unit Roots in Time Series Regression,' Biometrika, 75(2), 335-346.

Rebelo, Sergio (2005) 'Real Business Cycle Models: Past, Present, and Future', NBER Working Paper, n¹1401.

Shapiro, Mattew and Mark W. Watson (1988) 'Sources of Business Cycle Fluctuations ', Cowles Foundation Discussion paper, $n^{\circ} 870$.

Sims, Christopher A. (1980) 'Macroeconomics and Reality', Econometrica, 48(1): $1-48$.

Slutsky, Eugen (1927) 'The Summation of Random Waves as the Sources of Cyclic processes', in Problems of Economic Conditions, ed, Conjuncture Institute, Moskva, 3(1). Revised English Version, 1937, in Econometrica, 5(2): 105-146. 